\title{
The effect of dietary commercial enzyme preparations on performance of broilers
}

\author{
K Benabdeljelil 1, MI Arbaoui 2 \\ 1 Institute of Agronomy and Veterinary Medicine Hassan II BP 6202 Rabat-Instituts; \\ 2 Service d'Élevage de Fes, Morocco
}

(Received 11 April 1991; accepted 20 November 1991)

\begin{abstract}
Summary - The effects on broiler performance of 2 commercial enzyme mixtures as supplements to barley- based diets were investigated in 3 experiments. The results of these studies indicate that some improvements in growth rate and feed utilization were obtained but were not always consistent and significant when broilers were fed the test diets from 2 to 8 weeks of age. The enzyme preparation SP 343 had a more consistent influence on diet utilization of broilers fed from 1 day of age to 8 weeks. No significant differences were observed by doubling the dose of SP 343.
\end{abstract}

barley / broiler / enzyme

Résumé - Les effets de deux préparations enzymatiques commerciales sur les performances de poulets de chair. Trois essais ont été conduits dans le but de tester les effets de deux préparations enzymatiques commerciales sur les performances de poulets de chair recevant des aliments à base d'orge. Quelques améliorations relatives au croît et à l'efficacité alimentaire ont été enregistrées chez des poulets recevant les régimes expérimentaux de 2 à 8 semaines d'âge; elles n'étaient cependant pas toujours significatives et répétables. La préparation enzymatique SP 343 a eu une influence plus constante sur l'indice de consommation des animaux recevant les régimes du premier jour jusqu'à 8 semaines d'âge. Le doublement de la dose de SP 343 n'a pas eu d'effet significatif additionnel.

poulet de chair / orge / enzyme

\section{INTRODUCTION}

The inclusion of barley in broiler feed has been rather limited due to its inconsistent nutritional value and frequent coritribution to the production of sticky droppings and wet litter (Hesselman et al, 1981, 1982; Mannion, 1981).

Commercially produced enzyme mixtures have long been known to improve the growth of broilers fed barley-based diets (Fry et al, 1958; Arscott and Rose, 1960; Willingham et al, 1960; Delpech and Ezzat, 1979), but their resulting effects were not always consistent. Extensive summaries of experiments dealing with enzyme supplementation of barley diets and bird response have been provided in the review of Hesselman (1989). In recent years, renewed interest in the use of enzymes in broiler feed to improve the nutritional value of barley has made new commercial mixtures available mostly 
based on $\beta$-glucanase cellulase and protease activities.

Growth response to enzyme supplementation cannot, however, be assumed for broilers fed local barleys as any response is influenced by the genetic origin of the grain (Daghir and Rottensten, 1966; Coon et al, 1979; Mannion, 1981) the geographical area where the barley is grown (Willingham et al, 1960) and the nature and level of enzyme supplements in the diets (Anderson et al, 1961; Rose and Arscott, 1962; Herstad and McNab, 1975; Rotter et al, 1989).

The objective of the current study was to evaluate the efficacy of 2 commercial enzyme preparations when added to barley based diets fed to broiler chicks of different ages.

\section{MATERIALS AND METHODS}

\section{General procedure}

In all experiments straight run day-old broilers were obtained from a commercial hatchery and randomly assigned to floor pens. They were Arbor acre strains in experiments 1 and 2 and $\mathrm{In}$ dian River in experiment 3.

Locally available barley of unknown genetic origin and geographical area was incorporated into the test diets and no adjustment was made for its me:abolizable energy content in these experiments when fed with enzyme supplements. The barley used in experiments 1 and 2 was supplied from a different batch than that utilized in experiment 3 (table I).

The composition of the basal diets used in the experiments is shown in table II. Analyses were performed by AOAC 1980 methods of barley and diets' chemical compositions. Common
Table I. Proximate composition of barley.

\begin{tabular}{lcr}
\hline & \multicolumn{2}{c}{ Experiments } \\
& 1 1 and 2 & 3 \\
\hline & & \\
Dry matter & 89.52 & 89.60 \\
Crude proteins & 10.93 & 10.83 \\
Crude fiber & 5.56 & 9.52 \\
Ash & 7.47 & 7.01 \\
\hline
\end{tabular}

lots of diet were prepared in the studies and sub-quantities were taken for mixing in each of the test diets. The experimental diets were thus mixed a week prior to the beginning of each experiment and were kept in a cool place. All diets were isocaloric $(2850 \mathrm{Kcal} / \mathrm{Kg})$ and isonitrogenous $(21 \%$ proteins $1.11 \%$ lysine and $0.83 \%$ sulfuro-amino acids) within each experiment and were fed ad libitum. The birds also had free access to water. Two commercial enzyme supplements have been tested, namely *: Kemzyme, obtained from Kemin France, and "SP 343", received from NOVO Industries Enzymes SA. Enzyme supplements were blended with approximately $40 \mathrm{~kg}$ of the basal diet before being added to the final mixture.

\section{Measurements and analyses}

The birds from each floor pen were collectively weighed and pen feed consumption data were taken at intervals throughout each experiment. Mortality was recorded as it occurred and all birds were weighed as soon as possible after death.

The pen effect was taken into consideration regarding the weight of the dead birds in the calculation of body weight gain and feed efficiency. In all trials, the obtained data were subjected to analysis variance and treatment means were compared using Duncan's multiple range test (Duncan, 1955).

\footnotetext{
* The use of trade names implies neither endorsement of the enzymes mixtures named nor criticism of similar compounds not mentioned.
} 
Table II. Composition of experimental diets.

\begin{tabular}{|c|c|c|c|c|c|c|}
\hline \multirow[t]{2}{*}{ Ingredients } & & \multicolumn{5}{|c|}{ Experiments } \\
\hline & & \multicolumn{2}{|c|}{$\begin{array}{l}1 \text { and } 2 \\
(\%)\end{array}$} & \multirow{2}{*}{30.00} & & \multirow{2}{*}{$\begin{array}{c}3 \\
(\%)\end{array}$} \\
\hline Barley & - & 10.00 & 20.00 & & 40.00 & \\
\hline Corn & 56.34 & 49.00 & 41.69 & 37.68 & 31.26 & 30.40 \\
\hline Peas & 10.00 & 10.00 & 10.00 & 0.45 & - & - \\
\hline Molasses & 2.00 & 2.00 & 2.00 & 2.00 & - & 2.00 \\
\hline Cotton seed meal & 6.00 & 6.00 & 6.00 & 6.00 & 6.00 & 6.00 \\
\hline Sunflower meal & 6.00 & 6.00 & 6.00 & 6.00 & 5.28 & 5.98 \\
\hline Soybean meal & 11.44 & 6.57 & 1.70 & 4.71 & 4.35 & 1.01 \\
\hline Fish meal $(55 \%$ CP) & 2.00 & 2.00 & 2.00 & 2.00 & 2.00 & 2.00 \\
\hline Fish meal $(65 \%$ CP) & 4.20 & 6.77 & 9.32 & 10.00 & 10.00 & 12.00 \\
\hline DL-Methionine & 0.13 & 0.11 & 0.09 & 0.07 & 0.07 & 0.05 \\
\hline Calcium carbonate & 0.33 & 0.38 & 0.42 & 0.44 & 0.21 & - \\
\hline Bone powder & 0.88 & 0.53 & 0.18 & 0.06 & 0.04 & - \\
\hline Salt & 0.18 & 0.14 & 0.10 & 0.09 & 0.09 & 0.06 \\
\hline Vitamin-mineral mix ${ }^{1}$ & 0.50 & 0.50 & 0.50 & 0.50 & 0.50 & 0.50 \\
\hline \multicolumn{7}{|l|}{ Chemical analysis (\%) } \\
\hline Proteins & 22.86 & 23.10 & 23.81 & 23.67 & 23.23 & 23.50 \\
\hline Crude fiber & 4.52 & 5.07 & 5.36 & 5.68 & 5.66 & 6.10 \\
\hline Ash & 7.33 & 7.72 & 7.45 & 7.31 & 7.08 & 8.81 \\
\hline Dry matter & 89.59 & 89.19 & 89.00 & 89.26 & 88.82 & 90.30 \\
\hline
\end{tabular}

1 Vitamin mineral pre-mix supplied per $\mathrm{kg}$ of diet vitamin $\mathrm{A} 1000 \mathrm{lU}$; vitamin $\mathrm{D}_{3} 3000 \mathrm{IU}$; vit $\mathrm{E} 10 \mathrm{mg} ;$ vit $\mathrm{B}_{12} 8 \mu \mathrm{g}$; vit K $1.8 \mathrm{mg}$; riboblavin $4.0 \mathrm{mg}$; Ca panthotenate $10 \mathrm{mg}$; niacin $24 \mathrm{mg}$; choline $0.35 \mathrm{mg}$; folic acid $0.6 \mathrm{mg}$; Co 0.4 $\mathrm{mg}$; Cu $8 \mathrm{mg}$; Fe $25 \mathrm{mg}$; $21.1 \mathrm{mg}$; Mn $80 \mathrm{mg}$; Se $0.2 \mathrm{mg}$; Zn $50 \mathrm{mg} .{ }^{2}$ In experiment 1: Kemzyme was added at $0.05 \%$ to the basal diets containing 0.1020 and $30 \%$ barley (see table III). In experiment 2: Kemzyme and SP 343 were added to the basal diets containing 20 and $30 \%$ barley respectively at $0.05 \%$ (see table IV). In experiment 3 : The 10 and $30 \%$ barley based diets used in experiments 1 and 2 were $f$ ed. $0.4 \%, 0.8 \%$ SP 343 were added to a $30 \%$ and a $40 \%$ barley based diet as shown in table $\mathrm{V}$.

\section{Experiments 1 and 2}

Nine hundred and sixty-d-old broilers were used in each experiment. They were fed a commercial starting diet for 2 weeks and thereafter randomly divided into 16 equal weight groups of 60 birds each. Test diets consisted of a $0,10,20$ and $30 \%$ barley based diet as shown in table II supplemented or not with $0.05 \%$ Kenzyme and were fed until 57 days of age in experiment 1 .

In experiment 2, the birds were fed a control diet with $10 \%$ barley with or without $0.05 \% \mathrm{SP}$ 343 and a $30 \%$ or $40 \%$ barley based diet supplemented or not with $0.05 \%$ Kenzyme or SP
343 respectively, as shown in table IV. The data were submitted to analysis of variance in a $2 \times 4$ factorial design (experiment 1 ) and in a completely randomized design (experiment 2).

\section{Experiment 3}

Two levels of the enzyme mixture SP 343 were used in this experiment: 0.04 and $0.08 \%$, respectively supplemented a 30 and $40 \%$ barleybased diet. These were fed with a control diet ( $10 \%$ barley) to 960 -day-old broilers until 52 days of age. Three pens of 64 chicks (randomly 
allocated to the pens) having equal group weights were used for each of the 5 dietary treatments.

\section{RESULTS}

Broilers' body weights, feed consumption, feed efficiency and litter moisture data are summarized in tables III, IV and V. Mortality was low in all experiments and dietary treatments had no overall significant effect on this parameter. Similarly, the number of males and females counted per pen at the end of each experiment did not vary significantly between the groups fed the test diets. Broilers fed $0 \%$ barley gained more weight than those fed barley diets regardless of Kemzyme addition but this effect was not significant (table III).
The non-supplemented barley diets resulted in a slightly lower gain for the period 14 to 57 days. Kemzyme supplementation improved broilers' weight gains in the 10 and $20 \%$ barley diets to approach that of the control diet (0\% barley) in experiment 1 (table III). Feed intake decreased as dietary barley levels increased. The addition of SP 343 to a $10 \%$ barley diet resulted in significant improvement in feed consumption and weight gains at 56 days of age. These effects were not, however, observed at higher levels of barley inclusion regardless of the enzyme mixture supplement. No significant effects were observed on feed to weight gain ratios (table IV). In experiment 3, no major improvement in broiler performance was registered when the dose of SP 343 was doubled from 0.04 to $0.08 \%$ in a $30 \%$ or $40 \%$ barley diet (table V).

Table III. Effects of dietary "Kemzyme" addition on broilers' performance from experiment 1 (14 to 57 days of age $)^{\dagger}$.

\begin{tabular}{|c|c|c|c|c|c|c|c|c|c|}
\hline \multirow[t]{3}{*}{ Kemzyme (\%) } & \multicolumn{8}{|c|}{ Barley (\%) } & \multirow{3}{*}{$P S E M^{2}$} \\
\hline & \multicolumn{2}{|c|}{0} & \multicolumn{2}{|c|}{10} & \multicolumn{2}{|c|}{20} & \multicolumn{2}{|c|}{30} & \\
\hline & 0.00 & 0.05 & 0.00 & 0.05 & 0.00 & 0.05 & 0.00 & 0.05 & \\
\hline $\begin{array}{l}\text { Body weight (g) } \\
\text { At } 14 \mathrm{~d} \\
\text { At } 57 \mathrm{~d}\end{array}$ & 202 & 209 & 201 & 194 & 196 & 200 & 205 & 205 & 11.4127 \\
\hline Males & 2430 & 2370 & 2220 & 2320 & 2250 & 2320 & 2190 & 2200 & 295.3845 \\
\hline Females & 1890 & 1990 & 1850 & 1970 & 1880 & 2010 & 1840 & 1860 & 135.7424 \\
\hline Body weight gain (g) & & & & & & & & & \\
\hline $\begin{array}{l}14-57 \mathrm{~d} \\
\text { Mortality }(\%)\end{array}$ & 1995 & 1989 & 1774 & 1973 & 1861 & 1981 & 1830 & 1842 & 170.5931 \\
\hline $14-57 \mathrm{~d}$ & 6.50 & 5.50 & 5.50 & 6.50 & 7.00 & 7.00 & 7.50 & 5.00 & 0.0626 \\
\hline Feed consumption g/bird & & & & & & & & & \\
\hline $\begin{array}{l}14-57 \mathrm{~d} \\
\text {. }\end{array}$ & 4982 & 4939 & 4723 & 5073 & 4960 & 5020 & 4840 & 4780 & 270.0222 \\
\hline $14-57 \mathrm{~d}$ & 2.498 & 2.485 & 2.667 & 2.573 & 2.652 & 2.519 & 2.646 & 2.598 & 0.1205 \\
\hline
\end{tabular}

\footnotetext{
1 No significant differences were observed between the measured parameters means in this experiment; ${ }^{2}$ Pooled standard error of the means.
} 
Table IV. Comparative effects of 2 enzyme preparations added to high barley diets on broiler performance ( 14 to 56 days) in experiment 2.

\begin{tabular}{|c|c|c|c|c|c|c|c|c|c|}
\hline $\begin{array}{l}\text { Barley (\%) } \\
\text { Enzymes (\%) }\end{array}$ & $0.00^{10}$ & $\begin{array}{l}10 \\
0.05 \% \\
S P 343\end{array}$ & ${ }_{K E}^{0.00}$ & $\begin{array}{r}30 \\
0.05 \% \\
e m z y m e\end{array}$ & $\begin{array}{c}0.05 \% \\
S P 343\end{array}$ & 0.00 & $\begin{array}{c}40 \\
0.05 \% \\
\text { Kemzyme }\end{array}$ & $\begin{array}{c}0.05 \% \\
S P 343\end{array}$ & PSEM 1 \\
\hline \multicolumn{10}{|l|}{ Body weight (g) } \\
\hline $\begin{array}{l}\text { At } 14 \text { days } \\
\text { At } 56 \text { days }\end{array}$ & 203 & 212 & 208 & 208 & 207 & 211 & 205 & 202 & 11.467 \\
\hline Males & 2388 & 2364 & 2235 & 2330 & 2109 & 2197 & 2168 & 2086 & 213.7569 \\
\hline $\begin{array}{l}\text { Females } \\
\text { Bodv weiaht aain (a) }\end{array}$ & 1873 & 2046 & 1859 & 1870 & 1909 & 1967 & 1751 & 1814 & 185.2782 \\
\hline $\begin{array}{l}14-56 \text { days } \\
\text { Mortality }(\%)\end{array}$ & $1920^{b}$ & $2015^{a}$ & $1816^{c}$ & $1915^{b}$ & $1805^{c d}$ & $1872^{\mathrm{bc}}$ & c $1728^{\circ}$ & $1736^{\mathrm{de}}$ & 60.2661 \\
\hline $\begin{array}{l}14-56 \text { days } \\
\text { Feed consumption (a }\end{array}$ & 7.50 & 6.00 & 4.00 & 7.00 & 5.50 & 4.00 & 6.00 & 6.00 & 0.0406 \\
\hline $\begin{array}{l}14-56 \text { days } \\
\text { Feed to gain ratio }\end{array}$ & $4366^{\text {bed }}$ & $4705^{a}$ & $4390^{\mathrm{bc}}$ & $4441^{b}$ & $4271^{\text {cdo }}$ & $4497^{b}$ & $4217^{\text {de }}$ & $4185^{\circ}$ & 139.0252 \\
\hline 14-56 days & 2.274 & 2.336 & 2.418 & 2.319 & 2.367 & 2.403 & 2.441 & 2.441 & 0.0564 \\
\hline
\end{tabular}

1 Pooled standard error of the means; ${ }^{a}, b, c, d, \theta$ Means along a line having different superscripts are significantly different $(P<0.05)$.

Table V. Effect of SP 343 dose on broiler performance experiment 3 (0-52 d).

\begin{tabular}{|c|c|c|c|c|c|c|}
\hline \multirow{2}{*}{$\begin{array}{l}\text { Barley (\%) } \\
\text { SP } 343 \text { (\%) }\end{array}$} & \multirow{2}{*}{$\begin{array}{l}10 \\
-\end{array}$} & \multicolumn{2}{|c|}{30} & \multicolumn{2}{|c|}{40} & \multirow[t]{2}{*}{ PSE $M^{1}$} \\
\hline & & 0.04 & 0.08 & 0.04 & 0.08 & \\
\hline $\begin{array}{l}\text { Body weight gain }(\mathrm{g}) \\
\text { Feed consumption }(\mathrm{g}) \\
\text { Feed to gain ratio }\end{array}$ & $\begin{array}{l}2106 \\
4864 \\
2.310^{a}\end{array}$ & $\begin{array}{l}2157 \\
4841 \\
2.244^{b c}\end{array}$ & $\begin{array}{l}2125 \\
4743 \\
2.232^{c}\end{array}$ & $\begin{array}{l}2079 \\
4717 \\
2.269 \mathrm{bc}\end{array}$ & $\begin{array}{l}2102 \\
4763 \\
2.266^{b c}\end{array}$ & $\begin{array}{l}41.1987 \\
97.1597 \\
0.0254\end{array}$ \\
\hline
\end{tabular}

1 Polled standard error of the means; ${ }^{a, b}, c$ Means along each line having different superscripts are significantly different $(P<0.05)$.

\section{DISCUSSION}

At the time these experiments were conducted, it was common local practice that commercial broilers feed contained about
$10 \%$ barley, as in our control treatments (tables III, IV, V). The inclusion of high levels of home-grown barley was considered to be a useful means of utilizing the large surplus harvested. One of the primary ob- 
jectives of the experiments was the testing of a high barley level in broiler diets and it has successfully been demonstrated that a level of up to $40 \%$ can sustain comparable performances to that of the commercial control diet containing $10 \%$ barley (experiments 1 and 2). These results confirm those previously published by Piton et al (1979) and others, but appear to be in conflict with those of Coon et al (1979), Blum et al (1980), and Hesselmen et al (1981). The disagreement could be attributed to a lower $\beta$-glucane content in local barleys (table I) when compared to some European varieties and to the feeding periods considered in experiments 1 and 2 .

The nutritional value of barley appears to be more critical when fed to day-old birds but improves as the bird ages (Petersen, 1969). The addition of the commercial enzyme preparations sustained similar growth performances to the control diet containing $10 \%$ barley when the birds were fed the diets starting from 2 weeks of age. When SP 343 was included in the diet of broilers fed to market age in experiment 3 , higher weight gains were observed for the $30 \%$ barley diet at both levels of the enzymes, concomitant with a significantly lower feed to gain ratio. These results tend to support previous findings of Mannion (1981) where the response to enzyme supplementation of birds fed barley diets was found to be more significant in younger birds. This addition does not seem to be warranted throughout the life of the broiler as the magnitude of the growth response might narrow with age, as in experiment 3.

Numerous studies have confirmed that enzyme addition to barley-based diets increases their ME content and improves feed consumption and growth performance when fed to broilers (Leong et al, 1962; Potter et al, 1965; Broz and Frigg, 1986a, b; Hesselman and Amman
1986; Rotter et al, 1990). This effect has been attributed to a a higher digestibility value for fat, starch and nitrogen. Although feed consumption did not consistently increase following enzyme addition, bird performance and diet analysis tend to indicate that improved ME might account for the results of the experiments.

On the other hand, the broilers fed the enzyme preparations maintained numerically improved body weight gains and feed to gain ratios compared with the control diet at 42 and 57 days of age; these differences were not statistically significant (exp 1).

The present studies have shown that barley can be used up to $30 \%$ (from 14 days of age) and up to $40 \%$ (to market age) in a low energy diet for broilers when supplemented with commercial enzyme preparation. The lack of response to the enzymatic treatment may be attributed to an inappropriate enzyme mixture (a high $\beta$ glucanase activity with a low $\beta$-glucane content barley) and reemphasizes the need for evaluating the chemical composition of the substrate prior to the preparation of the enzyme mixiure. The mechanisms by which the multi-enzyme mixtures exert their effects on some performances remains to be investigated. However, further studies involving more animals per dietary treatment utilizing enzymatic preparation of known activities may be warranted to determine the effects of these dietary additives on bird performance.

\section{ACKNOWLEDGMENTS}

Partial support for these projects was provided by Cerna (Morocco), Kemin and De Novo Industries SA (France). Thanks are is extended to the personnal of the Skikima experimental station for their technical assistance and care with the birds. 


\section{REFERENCES}

Anderson JO, Dobson DC, Wagstaff RK (1961) Studies on the value of hulless barley chick diets and means of increasing this value. Poult Sci 40, 1571-1584

Association of Official Analytical Chemists (1980) Official Methods of Analysis. Assoc Offic Anal Chem, Washington DC, 13th edn

Arscott GH, Rose RG (1960) Use of barley in high efficiency broiler rations. 4 . Influence of amylolytic enzymes on efficiency of utilization, water consumption and litter condition. Poult Sci 39, 93-95

Blum JC, Piton P, Gautheir A (1980) Etude préliminaire sur les constituants responsables de la mauvaise utilisation de l'orge chez le jeune poulet. Reprod Nutr Dev 20, 1717-1722

Broz J, Frigg $M$ (1986a) The effects of $\beta$ glucanase on the feeding value of broiler diets based on barley or oats. Arch Geflügelk 50, 41-47

Broz J, Frigg M (1986b) Effects of cellulolytic enzyme products on the feeding value of various broiler diets. Arch Geflügelk 50, 104-109

Goon CR, Shepler R, Mc Farland D, Nordheim J (1979) Nutritional evaluation of barley selections and cultivars from Washington state. Poult Sci 59, 913-918

Daghir NJ, Rottensten K (1966) The influence of variety and enzyme supplementation on the nutritional value of barley for chicks. Br Poult Sci 7, 159-163

Delpech P, Ezzat F (1979) Valorisation des régimes a base d'orge pour les poulets de chair par addition d'enzymes diverses. In: Matières Premières et Alimentation des Volailles. INRA, 33-42

Duncan DB (1955) Multiple range and multiple $F$ tests. Biometrics 11, 1-42

Fry RE, Alired JB, Jensen LS, Mc Ginnis J (1958) Influence of enzyme supplementation and water treatment on the nutritional value of different grains for poults. Poultry Sci 37, 372-375

Herstad O, McNab JM (1975) The effect of heat treatment and enzyme supplementation on the nutritive value of barley for broiler chicks. Br Poult Sci 16, 1-8

Hesselman K, Elwinger K, Nilsson M, Thomke S (1981) The effect of $\beta$-glucanase supplementation stage of ripeness and storage of barley diets fed to broiler chicks. Poult Sci 60, 26642671

Hesselman K, Elwinger K, Thomke S (1982) Influence of increasing levels of $\beta$-glucanase on the productive value of barley diets for broiler chickens. Anim Feed Sci Tech 7, 351 358

Hesselman K, Aman P (1986) The effect of $\beta$ glucanase on the utilization of starch and nitrogen by broiler chickens fed on barley of low or high viscosity. Anim Feed Sci Tech 15, 83-89

Hesselman K (1989) The use of enzymes in poultry diets. Proc 7th Eur Symp on Poultry Nutr, June 19-21 WPSA

Leong KC, Jensen LS, Mc Ginnis J (1962) Effects of water treatment and enzyme supplementation on the metabolizable energy of barley. Poult Sci 41, 36-39

Mannion PF (1981) Enzyme supplementation of barley diets for broiler chickens. Aust $J$ Exp Agric Anim Husb 21, 296-302

Petersen VE (1969) A comparison of the feeding value for broilers of corn, grain sorghum, barley, wheat and oats, and the influence of the various grains on the composition and taste of broiler meat. Poult Sci 48, 2006-2013

Piton PS, Guillaumin, Leclercq B, Blum JC (1979) Valeur alimentaire de différentes variétés d'orge pour le poulet en croissance. Role possible des $\beta$-glucanes. J Matières Premières et Alimentation des Volailles INRA, 135-146

Potter LM, Stutz MW, Matterson LD (1965) Metabolizable energy and digestibility coefficients of barley for chicks as influenced by water treatment or by presence of fungal enzyme. Poult Sci 44, 565-573

Rose RJ, Arscott GH (1962) Use of barley in high efficiency broiler rations. 5. Further studies on the use of enzyme, soaking and pelleting barley for chicks. Poult Sci 41, 124-130 
Rotter BA, Neskar M, Marquardt RR, Gunter W (1989) Effects of different enzyme preparations on the nutritional value of barley in chicken diets. Nutr Rep Int 39 (1), 107-120

Rotter BA, Friesen OD, Guenter W, Marquardt RR (1990) Influence of enzyme supplemen- tation on the bioavailable energy of barley. Poult Sci 69, 1174-1181

Willinghan JE, Leong KC, Jensen LS, Mc Ginnis $J(1960)$ Influence of geographical area of production on response of different barley samples to enzyme supplements or water treatment. Poult Sci 39, 103-108 